\title{
KAJIAN MANFAAT KEMANGI (OCIMUM BASILICUM) TERHADAP HALITOSIS
}

\author{
Hilmiy Ila Robbihi ${ }^{1}$ \\ ${ }^{1}$ Dental Therapy, Poltekkes Kemenkes Tasikmalaya, Jawa Barat, Indonesia \\ *hilmiyilarobbihi@gmail.com
}

\section{Kata kunci:}

Kemangi (Ocimum Basilicum), Halitosis

ABSTRAK zmmmsmsssssVZKAZJAZ,AZL

Penelitian ini bertujuan untuk mengetahui manfaat kemangi (ocimum basilicum) terhadap halitosis Penelitian ini adalah penelitian kualitatif yang bersifat studi pustaka (library research) yang menggunkan buku-buku dan literatur-literatur lainnya sebagai objek yang utama. Litertaratur yang dikaji yaitu berupa hasil penelitian mengenai manfaat kemangi dan literatur terhadap manfaat kemangi (ocimum basilicum) terhadap halitosis. Berdasarkan hasil elaborasi data yang didapat maka dapat disimpulkan bahwa Kemangi memiliki kandungan flavonoid bersifat antimikroba yang mampu mencegah masuknya bakteri, virus, atau jamur yang membahayakan tubuh. Selain itu, flavonoid berperan secara langsung sebagai antibiotik dengan mengganggu fungsi dari mikroorganisme, dan efek farmakologis yang dimiliki seluruh bagian kemangi diantaranya menghilangkan bau badan dan bau mulut. Eugenol berperan sebagai antioksidan, yang dapat menetralkan radikal bebas, menetralkan kolesterol dan bersifat antikanker. Minyak atsiri, mudah menguap dan mempunyai aktivitas biologis sebagai antimikroba

Key word:

Basil Flower (Ocimum

Basilicum), Halitosis

\section{ABSTRACT}

This study aims to determine the benefits of basil (ocimum basilicum) against halitosis. This research is a qualitative study of library research that uses books and other literature as the main object. The literature studied is in the form of research results on the benefits of basil and literature on the benefits of basil (ocimum basilicum) on halitosis. Based on the results of the elaboration of the data obtained it can be concluded that Basil has antimicrobial flavonoids that are able to prevent the entry of bacteria, viruses, or fungi that endanger the body. In addition, flavonoids act directly as an antibiotic by interfering with the function of microorganisms, and the pharmacological effects of all parts of the basil include eliminating body odor and bad breath. Eugenol acts as an antioxidant, which can neutralize free radicals, neutralize cholesterol and is anticancer. Essential oils, volatile and have biological activity as an antimicrobial 


\section{PENDAHULUAN}

Perkembangan kesehatan di Indonesia diarahkan untuk mencapai visi kesehatan yaitu "Masyarakat sehat yang mandiri dan berkeadilan", dengan tujuan terselenggaranya pembangunan kesehatan dan untuk meningkatkan kesadaran, kemauan dan kemampuan hidup sehat bagi setiap orang dalam rangka mencapai derajat kesehatan masyarakat yang setinggi-tingginya. Investasi pembangunan sumber daya manusia yang produktif secara sosial dan ekonomi juga dalam memberi pelayanan kesehatan diupayakan adil dan merata. Pelayanan kesehatan gigi dan mulut dilaksanakan untuk memelihara dan meningkatkan derajat kesehatan masyarakat, yaitu dalam bentuk peningkatan kesehatan gigi, pencegahan penyakit gigi, pengobatan penyakit gigi dan pemulihan kesehatan gigi oleh pemerintah, pemerintah daerah atau masyarakat yang dilakukan secara terpadu, terintegrasi dan berkesinambungan (Kemenkes, R.I., 2012).

Hasil studi morbiditas Survei Kesehatan Rumah Tangga (SKRT), SUKSENAS (Survei Kesehatan Nasional) 2001 menunjukkan, dari 10 kelompok penyakit terbanyak yang dikeluhkan masyarakat, penyakit gigi dan mulut menduduki urutan pertama (60\%). Angka itu bukan merupakan angka yang dapat diabaikan karena telah terbukti bahwa penyakit gigi dan mulut dapat secara signifikan mempengaruhi produktifitas masyarakat (Ghofur, 2012). Penyakit gigi dan mulut merupakan penyakit tertinggi ke-6 yang dikeluhkan masyarakat Indonesia menurut Survei Kesehatan Rumah Tangga (SKRT) dan menempati peringkat ke-4 penyakit termahal dalam pengobatan menurut The World Oral Health Report tahun 2003, ada dua penyakit gigi dan mulut yang mempunyai prevalensi cukup tinggi di Indonesia yaitu karies dan penyakit periodontal (Pintauli, dan Hamada, 2008).

Roeslan (1999) menyatakan hasil survei di Amerika Serikat, penyebab utama halitosis sebagian besar (90\%) karena faktor-faktor yang melibatkan rongga mulut. Rongga mulut merupakan bagian saluran cerna dengan biologi yang unik, terdiri atas jaringan lunak dan keras seperti tubuh lainnya, dalam rongga mulut ini juga terdapat kelainan-kelainan, salah satunya yaitu bau mulut atau halitosis, diperkuat oleh Diansyah (2009), halitosis adalah suatu keadaan yang berhubungan dengan bau yang mempunyai sumber di dalam rongga mulut atau di luar rongga mulut, halitosis bukanlah suatu penyakit, tetapi dianggap sebagai gejala dari penyakit sistemik tertentu, namun bukan berarti bahwa setiap bau yang tidak sedap menandakan adanya suatu penyakit tertentu.

Halitosis yang bersumber dari mulut merupakan faktor yang disebabkan oleh bakteri dan protein yang ada pada semua orang, karena pada dasarnya halitosis adalah masalah semua orang yang kebanyakan tidak menyadari bahwa dirinya memiliki masalah bau mulut. Tingkat keparahan halitosis yang berbeda, ada yang mempunyai halitosis ringan sehingga sama sekali tidak mengganggu orang-orang di sekitarnya, sementara yang mempunyai kondisi halitosis berat sangat mengganggu orang lain sehingga dapat mempengaruhi rasa percaya diri. Halitosis merupakan keluhan yang umum dan populer dikenal sebagai nafas yang berbau menyengat, seperti nafas bau sementara termasuk sesudah makan sesuatu, seperti bawang putih atau bawang merah dan beberapa obatobatan, seperti paraldehyde (Djaya, 2000). Munculnya bau tidak sedap tersebut disebabkan oleh beberapa hal, namun yang paling sering adalah adanya masalah pada organ pencernaan serta kondisi kesehatan gigi dan mulut yang tidak baik (Tilong, 2012).

Para ahli mencatat ada sekitar 90 kasus bau mulut kronis yang disebabkan oleh perkembangbiakan bakteri pada bagian bawah lidah, bagian ini sangat rawan karena sering dilupakan saat menggosok gigi. Bakteri sangat gemar hidup dan berkembang biak di tempat gelap dan sulit dijangkau dalam mulut (Tilong, 2012). Hampir 90\% penyebab halitosis adalah bakteri penghasil sulfur yang tinggal di bagian belakang mulut, hal ini erat kaitannya dengan kebersihan mulut yang tidak terjaga sehingga menyebabkan gigi 
berlubang, infeksi gusi dan xerostomia, untuk menjaga kebersihan mulut pada umumnya masyarakat mengatasi hal tersebut dengan cara menyikat gigi, penggunaan obat kumur, permen karet dan pemakaian tanaman obat sebagai upaya penanggulangan masalah kesehatan yang telah banyak diterapkan masyarakat di tengah-tengah kemajuan teknologi dan ilmu pengetahuan saat ini, terlebih lagi keadaan perekonomian Indonesia saat ini yang mengakibatkan harga obat-obatan relatif mahal akibatnya masyarakat memilih pengobatan secara tradisional dan menggunakan obat tradisional (Djaya, 2000).

World Health Organitation (WHO) pada tahun 2008 mengestimasi bahwa hampir $80 \%$ penduduk dunia menggunakan obat dari bahan alam untuk mendukung kesehatan alam. Indonesia mempunyai potensi yang besar dalam pengembangan obat dari bahan alam atau dari tanaman obat yang digunakan sebagai obat tradisional. Penggunaan obat alami di Indonesia yang dikenal sebagai jamu telah dimanfaatkan sejak zaman nenek moyang hingga kini dan terus dilestarikan sebagai warisan budaya Indonesia yang dianugerahi kekayaan keanekaragaman hayati tersebut, memiliki lebih dari 30.000 jenis tanaman. Hingga saat ini, tercatat 7.000 spesies tanaman telah diketahui khasiatnya, namun baru kurang dari 300 tanaman yang digunakan sebagai bahan baku industri farmasi secara regular (Sardjono, 1994).

Indonesia kaya akan berbagai macam tanaman obat yang telah digunakan secara turun temurun sebagai obat tradisional. Salah satu tanaman obat yang terdapat di Indonesia adalah daun kemangi (ocimum basilicum). Kemangi digunakan masyarakat sebagai sayur atau lalap, selain sebagai lalapan, kemangi juga mempunyai khasiat mengatasi bau mulut dan badan, badan lesu serta panas dalam (Wiyono, dkk., 2013).

Menurut "Daftar Komposisi Bahan Makanan" Direktorat Gizi Departemen Kesehatan RI, termasuk sayuran kaya provitamin A, setiap 100 gr daun kemangi terkandung 5.000 SI vitamin A. Kelebihan lainnya, kemangi termasuk sayuran yang banyak mengandung mineral kalsium dan fosfor, yaitu sebanyak 45 dan $75 \mathrm{mg}$ per $100 \mathrm{gr}$ daun. Kemangi memiliki kandungan flavonoid bersifat antimikroba yang mampu mencegah masuknya bakteri, virus, atau jamur yang membahayakan tubuh, selain itu flavonoid berperan secara langsung sebagai antibiotik dengan mengganggu fungsi dari mikroorganisme (Johani, 2008). Penelitian ini bertujuan untuk mengetahui manfaat kemangi (ocimum basilicum) terhadap halitosis.

\section{METODE}

Penelitian ini adalah penelitian kualitatif yang bersifat studi pustaka (library research) yang menggunkan buku-buku dan literatur-literatur lainnya sebagai objek yang utama. Jenis penelitian yang digunakan adalah kualitatif, yaitu penelitian yang menghasilkan informasi berupa catatan dan data deskriptif yang terdapat di dalam teks yang diteliti (Mantra, 2008). Litertaru yang dikaji yaitu berupa hasil penelitian mengenai manfaat kemangi dan literatur terhadap manfaat kemangi (ocimum basilicum) terhadap halitosis.

\section{HASIL DAN PEMBAHASAN}

Masyarakat Indonesia pada umumnya suka menghindari makan-makanan yang berpotensi menimbulkan bau mulut seperti jengkol, durian, petai dan sebagainya. Bau mulut selain disebabkan oleh bakteri penyebab bau mulut juga disebabkan oleh sisa-sisa makanan yang tertinggal di dalam mulut. Hampir $90 \%$ penyebab bau mulut adalah bakteri penghasil sulfur yang tinggal di bagian belakang mulut, hal ini erat kaitannya dengan kebersihan mulut yang tidak terjaga sehingga menyebabkan gigi berlubang, infeksi gusi dan xerostomia (Budiyanto, dkk., 2008). 
Penyebab bau mulut bisa berasal dari mulut yang kotor, penyebab mulut yang kotor berasal dari makanan yang dimakan ataupun bakteri yang ada di dalamnya. Bakteri tersebut berinteraksi dengan partikel-partikel makanan, darah, jaringan dan sebagainya, jika tidak dibersihkan dengan baik, maka bakteri itu akan berkembang biak. Selain itu kondisi mulut yang kering dapat menjadi penyebab nafas tidak sedap atau bau mulut. Radang gusi dapat menyebabkan bakteri berkembang, namun mulut kering lebih sering menjadi penyebab utama bau mulut, karena menjadi lahan yang potensial bagi berkembangnya bakteri. Bau mulut juga bisa diakibatkan oleh mengkonsumsi makanan yang berbau menyengat, karena dapat menyebabkan keluarnya aroma nafas tidak sedap dari mulut, seperti bawang, alkohol dan tembakau. Penyebab bau mulut pada beberapa kondisi dapat menjadi pertanda penyakit yang lebih serius. Penyakit yang paling umum menyebabkan nafas tak sedap adalah diabetes atau GERD (Gastro Esophageal Reflux Diaseas) yang terjadi ketika asam lambung naik kembali ke kerongkongan sehingga menyebabkan ketidaknyamanan (Putra, 2012).

Penyakit yang paling umum menyebabkab napas tak sedap dapat menjadi pertanda penyakit yang lebih serius, seperti penyakit diabeter atau GERD (gastro esophageal reflux disease). Diabeter juga dapat menyebabkan ketosis. Napas tak sedap yang dihasilkan kerap menjadi gejala pertama yang digunakan untuk mendiagnosis penyakit ini, kemungkinan lain walaupun lebih kecil adalah penyakit ginjal atau hati. Racun dalam organ-organ tersebut mengalir ke paru-paru dan menyebabkan aroma napas tak sedap. Sala satu cara alternif yang murah meriah dan gampang adalah dengan rutin menyantap daun kemangi segar sebagai lalapan karena daun kemangi telah terbukti dapat mengurangi bau mulut (Putra 2012), selain itu kandungan flavonoid nya yang berperan secara langsung sebagai antibiotik dengan mengganggu fungsi dari mikroorganisme (Insani, 2012).

Beberapa penelitian telah dilakukan untuk mengetahui bakteri-bakteri spesifik penyebab bau mulut. Di dalam mulut normal diperkirakan rata-rata terdapat sekitar 400 macam bakteri dengan berbagai tipe (Praminingrat, 2012). Penyebab bau mulut, meskipun belum diketahui dengan jelas kebanyakan dari bau tersebut berasal dari sisa makanan di dalam mulut. Masalah akan muncul bila sebagian bakteri berkembang biak atau bahkan bermutasi secara besar-besaran. Kebanyakan dari bakteri ini bermukim di leher gigi bersatu dengan plak dan karang gigi, juga di balik lidah karena daerah tersebut merupakan daerah yang aman dari kegiatan mulut sehari-hari. Bakteri tersebut memproduksi toxin atau racun, dengan cara menguraikan sisa makanan dan sel-sel mati yang terdapat di dalam mulut. Racun inilah yang menyebabkan bau mulut pada saat bernafas karena hasil metabolisme proses anaerob pada saat penguraian sisa makanan tersebut menghasilkan senyawa sulfide dan ammonia, bakteri anaerob contohnya streptococcus, staphylococcus, dan corynebacterium (Diansyah, 2009).

Pemakaian tanaman obat sebagai upaya penanggulangan masalah kesehatan telah banyak digunakan masyarakat di tengah-tengah kemajuan teknologi dan ilmu pengetahuan saat ini. Terlebih lagi keadaan perekonomian Indonesia saat ini yang mengakibatkan harga obat-obatan relatif mahal. Salah satu tanaman obat yang sering digunakan oleh masyarakat ialah kemangi (Ocimum basillicum). Kemangi digunakan masyarakat sebagai sayur atau lalap. Selain sebagai lalapan, kemangi juga mempunyai khasiat mengatasi bau mulut dan badan, badan lesu serta panas dalam. Selain itu, tanaman ini juga digunakan sebagai peluruh haid dan peluruh ASI. Penelitian tentang khasiat daun kemangi sebagai antibakteri telah dilakukan, ekstrak etanol daun kemangi memiliki aktifitas antibakteri terhadap Staphylococcus Aureus dan Escherichia Coli (Wiyono, dkk., 2013).

Indonesia adalah negara yang kaya akan sumber daya dan hasil alam. Salah satu sumber daya alam yang belum dimanfaatkan secara optimal adalah kemangi. Kemangi yang berasal dari spesies ocimum basilicum tidak asing lagi bagi kita dan sering kita 
jumpai dalam kehidupan sehari-hari. Kemangi memiliki kandungan yang berpengaruh terhadap halitosis yaitu berupa kandungan Minyak atsiri, flavonoid dan eugenol (Budiyanto, dkk., 2008). Sejak zaman dahulu, kemangi disuling untuk diambil sari minyak atsirinya. Menurut John Henry, dalam buku A Dictionary of Practical Material Medical, menggolongkan minyak kemangi sebagai atsiri yang berarti aroma kemangi segera hilang setelah 24 jam dioleskan ke tubuh. Perbandingan minyak atsiri kategori sedang akan hilang aromanya setelah 3 hari dioleskan, sedangkan minyak atsiri ketegori rendah, aromanya hilang setelah seminggu (Putra, 2012).

Minyak atsiri, mudah menguap dan mempunyai aktivitas biologis sebagai antimikroba. Minyak atsiri dibagi menjadi dua komponen, yaitu komponen hidrokarbon dan komponen hidrokarbon teroksigenasi atau fenol. Fenol memiliki sifat antimikroba sangat kuat. Minyak atsiri dapat mencegah pertumbuhan mikroba penyebab penyakit, seperti staphylococcus aureus, salmonella enteritidis, dan escherichia coli. Minyak atsiri juga dapat menangkal infeksi akibat virus basillus subtilis, salmonella paratyphi, dan proteus vulgaris. Flavonoid dan Eugenol berperan sebagai antioksidan, yang dapat menetralkan radikal bebas, menetralkan kolesterol dan bersifat antikanker. Senyawa ini juga bersifat antimikroba yang mampu mencegah masuknya bakteri, virus, atau jamur yang membahayakan tubuh. Flavonoid berperan secara langsung sebagai antibiotik dengan mengganggu fungsi dari mikroorganisme (Insani, 2010).. Selain itu, flavonoid merupakan setiap kelompok seyawa yang mengandung inti aromatik khusus dan secara luas tersebar pada tanaman tingkat tinggi,sering dalam bentuk pigmen. Sedangkan Eugenol merupakan analgesia dental dan antiseptik yang diperoleh dari kemangi atau sumber alam lainnya (Darmawan, 2012).

Menurut Hariana (2007), efek farmakologis yang dimiliki seluruh bagian kemangi diantaranya menghilangkan bau badan dan bau mulut, anastesi, antihepatitis, diuretik, analpetik, membantu mengatasi ejakulasi prematur, anti kholinesterase, merangsang aktivitas saraf pusat, melebarkan pembuluh kapiler, merangsang hormon estrogen, menguatkan hepar, merangsang ASI, melebarkan pembuluh darah, melancarkan sirkulasi, serta mencegah pengeroposan tulang. Kemangi biasa digunakan sebagai lalapan pada waktu makan untuk menghilangkan bau mulut mengkonsumsi daun kemangi paling sedikit 10 lembar setiap hari, maka masalah bau mulut dan bau badan akan berangsur-angsur menghilang, namun bagi yang tidak terlalu menyukai aroma dan rasa kemangi dapat meminum air rebusan daun kemangi yang dicampur dengan madu, gula merah atau gula jawa (Cahyani, 2014). Cara ini masih kurang efektif karena hanya dapat digunakan pada makanan tertentu dan penggunaan kemangi sebagai obat tradisional secara turun temurun yang telah dikenal oleh masyarakat dan telah didukung oleh data preklinik, namun perlu diingat bahwa obat bahan alam yang dianggap aman oleh masyarakat juga perlu diwaspadai, karena setiap bahan atau zat memiliki potensi bersifat toksik tergantung takarannya dalam tubuh serta sulitnya standarisasi obat tradisional (Syarif, A., 2008).

Kemangi dan tanaman sejenisnya yaitu selasih atau basil (ocimum basilicum) memiliki sejarah yang menarik, tanaman jenis ini pernah menjadi tanaman kerajaan di Prancis dan Italia. Banyak negara lainnya yang juga memanfaatkan tanaman ini sebagai obat tradisional, seperti Yunani, Filipina, Tanzania, Meksiko, dan negara-negara Amerika dan Eropa. Terlepas dari pembuktian secara ilmiah, kemangi dan selasih secara empiris telah digunakan dalam pengobatan tradisional untuk berbagai macam penyakit, baik di Indonesia ataupun negara-negara lain (Putra, 2012). 


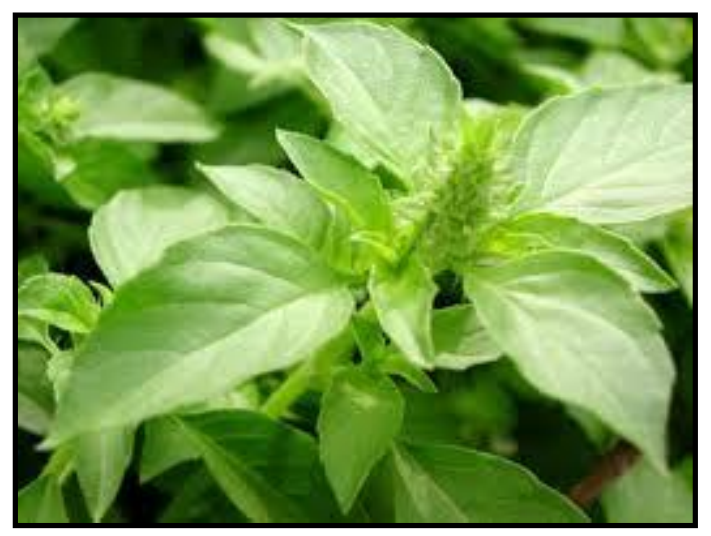

Gambar 1. Kemangi

(Cahyani, 2014)

Kemangi merupakan anggota famili biasa lamiaceae yang berarti kelompok tanaman dengan bunga berbibir. Nama genus kemangi adalah ocimum yang berarti tanaman beraroma. Aroma khas tersebut muncul dari daunnya, kemangi berkerabat dekat dengan tanaman selasih (Ocimun Sancium), daun mint (Mentha Arvensis), dan daun bangunbangun alias daun jinten (Coleus Amboinicus). Kerabat yang paling dekat dengan kemangi adalah basil (Ocimun Amboinicus) karena tumbuhnya menyemak, kemangi dikelompokkan dalam kelompok basil semak atau bush basil (Johani, 2008). Aroma khasnya berasal dari kandungan yang tinggi pada daun dan bunganya (Johani, 2008).

Menurut Budiyanto, dkk., (2008) dalam hasil penelitiannya menjelaskan bahwa permen herbal dari ekstrak daun kemangi memiliki daya hambat terhadap Streptococcus viridans yang jauh lebih baik daripada permen di pasaran. Untuk karakteristik kadar serat, air dan abu, semua sampel sesuai dengan spesifikasi standar nasional indonesia 3547.2/2008, pada penelitiannya kandungan flavonoid pada kemangi yang berperan penting untuk menghambat bakteri Streptococcus viridans sebagai faktor pemicu timbulnya bau mulut. Hasil penelitiannya diperoleh bahwa varian permen herbal dari ekstrak daun kemangi yang dapat menghambat pertumbuhan Streptococcus viridans secara maksimal adalah permen herbal dengan konsentrasi ekstrak daun kemangi $75 \%$, tetapi secara umum semua varian permen herbal dari ekstrak daun kemangi memiliki zona hambat yang lebih tinggi dari pada zona hambat permen yang ada di pasaran.

Cara lain mengatasi dan menanggulangi masalah bau mulut atau nafas tak sedap ialah menjaga kebersihan gigi dan mulut dengan menggosok gigi minimal 2 kali dalam sehari yaitu pada saat pagi hari sesudah sarapan dan malam hari sebelum tidur, selain itu pemeliharaan kebersihan gigi dan mulut dapat dibantu dengan Dental Floss (benang gigi) untuk membersihkan kotoran di sela-sela permuaan gigi. Umumnya setiap orang menggunakan pengharum atau penyegar nafas untuk menghilangkan bau mulut pada saatsaat mendesak, namun ini bukan penyembuh dan sifatnya hanya sementara. Menjaga kelembaban mulut merupakan cara terbaik untuk mengembalikan air ludah dengan meminum banyak air atau cairan, karena untuk mencegah timbulnya mulut kering (xerostomia). Menghindari makanan-makanan yang beraroma menyengat adalah cara terbaik untuk mencegah nafas tak sedap akibat makanan. Memperbanyak asupan karbohidrat merupakan salah satu untuk menghindari ketosis yang menyebabkan aroma nafas tak sedap. Mengunjugi dokter apabila berbagai cara sudah dicoba, tetapi nafas tak sedap tetap beraroma tidak sedap, mungkin aroma nafas tak sedap merupakan gejala dari suatu penyakit (Putra, 2012). 


\section{KESIMPULAN}

Berdasarkan hasil elaborasi data yang didapat maka dapat disimpulkan bahwa Kemangi memiliki kandungan flavonoid bersifat antimikroba yang mampu mencegah masuknya bakteri, virus, atau jamur yang membahayakan tubuh. Selain itu, flavonoid berperan secara langsung sebagai antibiotik dengan mengganggu fungsi dari mikroorganisme, dan efek farmakologis yang dimiliki seluruh bagian kemangi diantaranya menghilangkan bau badan dan bau mulut. Eugenol berperan sebagai antioksidan, yang dapat menetralkan radikal bebas, menetralkan kolesterol dan bersifat antikanker. Minyak atsiri, mudah menguap dan mempunyai aktivitas biologis sebagai antimikroba.

\section{DAFTAR PUSTAKA}

Budiyanto, E., Nirmala, W., Wardani, Y.A., dan Stiyawan., H., 2008, Pemanfaatan Ekstrak Daun Kemangi (Ocinum Canum) sebagai Permen Herbal Pencegah Bau Mulut, Jurnal Kesehatan, Jurusan Pendidikan Kimia Universitas Negeri Yogyakarta, Yogyakarta.

Darmawan, 2012, Kamus Istilah Kedokteran, PT. Gama Press, Surabaya.

Djaya, A., 2000, Halitosis Nafas Tidak Sedap, PT. Dental Lintas Mediatama, Jakarta.

Diansyah, J., 2009, Mekanisme Teh Hijau (Ryokucha) untuk Menghilangkan Halitosis yang Disebabkan oleh Kalkulus, Karya Tulis Ilmiah, Jurusan Kesehatan Gigi Politeknik Departemen Kesehatan Pontianak, Pontianak.

Cahyani, E.M., 2014, Daun Kemangi (Ocinum Cannum) sebagai Alternatif Pembuatan Handsanitizier, Jurnal Kesehatan Masyarakat, Fakultas Kesehatan Masyarakat Universitas Jember, Jember.

Ghofur, A., 2012, Buku Pintar Kesehatan Gigi dan Mulut, PT. Mitra Buku, Yogyakarta.

Hariana, A., 2007, Tumbuhan Obat dan Khasiatnya Seri 2, PT. Penebar Swadaya, Jakarta

Insani, L., 2010, Efek Minyak Atsiri Daun Kemangi (Ocimum Basilicum) sebagai Antidepresan pada Mencit Ditinjau dari Immobility Time pada Tail Suspension Test, Karya Tulis Ilmiah, Fakultas Kedokteran Universitas Diponegoro Semarang, Semarang.

Johani, E., 2008, Tanaman Pekarangan Pilihan, CV. Multi Trust Creative Service, Bandung.

Kementerian Kesehatan R.I., 2012, Undang-undang RI No.36 Tahun 2009 Tentang Kesehatan, Badan Pengembangan dan Pemberdayaan Sumber Daya Manusia. Jakarta. 
Kusuma, W., 2010, Efek Ekstrak Daun Kemangi (Ocimum Sanctum L) Terhadap Kerusakan Hepatosit Mencit Akibat Minyak Sawit dengan Pemanasan Berulang, Skripsi, Fakultas Kedokteran Universitas Sebelas Maret, Surakarta, Solo.

Mangoenprasodjo, S.A, 2004, Gigi Sehat Mulut Terjaga, PT. Think Fresh. Yogyakarta.

Mantra, B. I, 2008, Filsafat Penelitian \& Metode Penelitian Sosial, Pustaka Pelajar, Yogyakarta

Pintauli, S., dan Hamada, T., 2008, Fairway to Oral Health in General Practice. USU Press. Medan.

Praminingrat., 2012, Makalah IPM Halitosis, Fakultas Kedokteran Gigi Universitas Mahasaraswati Denpasar, Denpasar.

Putra, S.R., 2012, Khasiat Ajaib Kemangi, PT. Diva Press. Yogyakarta.

Ramadhan, G.A, 2010, Serba Serbi Kesehatan Gigi dan Mulut, PT. Bukune. Jagakarsa.

Roeslan, B.O., 1999, Peranan Biologi Oral dalam Bidang Kedokteran Gigi, Majalah Kedokteran Gigi Universitas Indonesia, Jakarta.

Sardjono, S.O., 1994, Perkembangan Obat Tradisional dalam Ilmu Kedokteran Indonesia dan Upaya Pengembangan sebagai Obat Alternatif, Skripsi, Fakultas Kedokteran Universitas Indonesia, Jakarta.

Susanto, W.G., 2011, Terapi Gusi untuk Kesehatan dan Kecantikan. PT. Erlangga. Jakarta.

Sutisna., Rudiyanto, D., dan Allwar., 2012, Konversi Sitral dalam Minyak Atsiri Kemangi (Ocimum citriodorum) dengan Metode MAOS (Microwave Assisted Organic Synthesis), Jurnal, Universitas Islam Indonesia, Jakarta.

Syarif, A., 2008 Perlu Bukti Khasiat dan Keamanan Obat Bahan Alam, Majalah Farmasi Universitas Diponegoro, Semarang.

Tilong, A.D., 2012, Deteksi Gangguan Kesehatan dengan Lidah, Bau Nafas, dan Urine, PT. Buku Biru, Yogyakarta.

Wiyono, W., Yamlean., P.V., dan Naibaho, O.H., 2013, Pengaruh Basis Salep Terhadap Formulasi Sediaan Salep Ekstrak Daun Kemangi (Ocimum Sanctum L.) pada Kulit Punggung Kelinci yang Dibuat Infeksi Staphylococcus Aureus, Jurnal Ilmiah Farmasi, Universitas Sumatera Utara, Medan. 